\section{AZ ELEKTRONIKUS KÖZVETÍTÉS SZABÁLYOZÁSÁRA KIADOTT MNB-AJÁNLÁS HÁTTERE ÉS HATÁSA}

Dr. Szikora Péter Pál (Magyar Nemzeti Bank, vezetö felügyelö) szikorap@mnb.hu

\section{ÖSSZEFOGLALÓ}

A biztosítási szektorban 2015 szeptemberében hatályosult a Magyar Nemzeti Bank 5/2015. (V. 05.) számú ajánlása a biztosítási termékek bemutatását, összehasonlítását szolgáló és a biztosításközvetítés során használt elektronikus felületekről (Ajánlás). Az Ajánlás európai szinten is előremutatóan fogalmaz meg elvárásokat a biztosítási piacon egyre nagyobb jelentőségű elektronikus felületekkel, folyamatokkal kapcsolatosan. Elismeri az elektronikus csatorna létjogosultságát, mint a közvetítői piac egyik markáns fejlődési irányát, valamint a csatornában rejlő lehetőségeket, ugyanakkor iránymutatást ad, megfelelő mederbe terel, erősítve a nem személyes biztosításközvetítői tevékenységgel szembeni közbizalmat. Az Ajánlásról az Európai Biztosítás- és Foglalkoztatóinyugdíj-hatóság (EIOPA - European Insurance and Occupational Pensions Authority) elnöke 2015. júliusban az MNB-hez eljuttatott levelében elismerően és támogatóan nyilatkozott, mint olyan nemzeti kezdeményezésről, amely a fogyasztóvédelmi szabályozás előmozdítása mellett elősegíti az elektronikus értékesítéssel kapcsolatos innovációkat is.

Az Ajánlással - annak jellegéből fakadóan is - az MNB irányt mutat, egyértelműsít a közvetítés ezen formájánál előforduló piaci bizonytalanságok eloszlatása érdekében, egyúttal meghatározza a piacon kívánatosnak, támogatottnak tartott elvárásokat és magatartást. Elsősorban elvárja a biztosításértékesítés ár-érték szerinti, szolgáltatásalapú szempontrendszerének alkalmazását, a korrekt (valós), könnyen érthető tájékoztatást, tényleges - minél teljesebb - igényfelmérést, a termékek értékesítésénél a csatorna korlátainak figyelembevételét, különösen összetett termékek esetén. Az MNB az Ajánlással - proaktív szabályozó szerepben - ugyanakkor keretet is kíván adni, illetve a jó gyakorlatok kiemelésével elöretekintően segíteni, további innovációra ösztönözni a piac szereplőit, ezzel élénkítve a versenyt a biztosítási szektorban.

Az Ajánlás hatását, egyes rendelkezéseinek teljesülését felmérve az MNB azt tapasztalta, hogy az Ajánlásban megfogalmazott célokat, elvárásokat a piac szereplői üdvözölték, azokat támogatva jellemzően beépítették, beépítik az értékesítési rendszerükbe. Az MNB elvárja az Ajánlás előírásainak történő megfelelést az Ajánlás hatálya alá tartozó szervezetektől, azt különböző módszerekkel méri, ellenőrzi. Az első eredmények azt mutatják, hogy már látható a piac, a piaci gyakorlatok elmozdulása a megfelelés, a magasabb szintű fogyasztói érdekek alkalmazásának irányába.

\section{SUMMARY}

The Recommendation no 5/2015 (V.05.) of the Magyar Nemzeti Bank on electronic platforms used for insurance mediation and for presentation and comparison of insurance products ('Recommendation') has taken effect in September 2015 concerning the insurance sector. The Recommendation sets out expectations prospectively at a European level for the electronic platforms and processes which have a growing importance in the insurance market. It acknowledges the legitimacy of electronic channels, as a strong evolving direction, as well as the potential opportunities for the channel, in the meantime it provides guidance, channeling guides, strengthening public confidence in intermediaries pursuing activity through electronic platforms.

The Chairman of the EIOPA (European Insurance and Occupational Pensions Authority) in his letter in July 2015 wrote that he views this national initiative as a very positive development and strongly supports such measures at national level to enhance consumer protection in the insurance sector and at the same time, promote innovation when it comes to selling insurance products online.

With the Recommendation - by its very nature - the MNB provides direction, clarifies in order to eliminate the existing uncertainties concerning the activities of such intermediaries, also to determine the desirable market expectations and conduct. Primarily it expects to use a feature and value-based insurance sales criteria, fair (actual) easily understandable information, actual - and more complete - demand analysis, the channel limitations which should be taken into account, especially for complex products. Through the Recommendation MNB - in its proactive regulatory role - sets the framework as well as prospectively helps to stimulate further innovation to market players by highlighting the good practices, thereby boosting competition within the insurance sector.

In assessing the fulfilment and effect of the Recommendation, and its certain provisions the MNB found that the goals and expectations of the Recommendation were welcomed and supported by the market participants and the market participants mostly involved these in their sales scheme. The Bank expects to comply with the provisions of the Recommendation from organizations within the scope of the Recommendation, it is monitored by various methods, and supervised. The first results show that the shifting of market or market conduct towards compliance and the application of a higher level of consumer interests could be seen already. 
Kulcsszavak: MNB-ajánlás, biztosításközvetítés, elektronikus biztosításértékesítés Key words: MNB recommendation, insurance mediation, electronic insurance distribution

\section{JEL: G20}

DOI: $10.18530 /$ BK.2016.3.58

http://dx.doi.org/1018530/BK.2016.3.58

\section{Előzmények és kihívások}

\section{I.1. Bevezetés}

Az elmúlt évtizedekben zajlott közvetítői piaci folyamatok kapcsán megállapítható, hogy az egyik legnagyobb hatású változást az elektronikus biztosításközvetítés megjelenése, megerösödése jelentette. Az elektronikus értékesítéssel színesedett a biztosítási piac, és gazdagodtak a biztosítási fedezetet kereső fogyasztók, valamint a társadalom is. Az elektronikus közvetítői tevékenység megerősödött, több tekintetben kiforrottá vált, ugyanakkor a személyes értékesítés továbbra sem helyettesíthető minden tekintetben. A két értékesítési mód, csatorna kiegészíti egymás tevékenységét a fogyasztók teljesebb kiszolgálása érdekében. Az elektronikus közvetítői piac szabályozása önmagában a tevékenység elismerését is jelenti, de az elismerés mellett a tevékenység végzésének korlátaival kapcsolatos bizonytalanságokat is meg kell szüntetni. Jelen cikkben az Ajánlás alapját képező körülményeket, a kiindulási helyzetet, a szabályozás mozgató elemeit, céljait és az eszközének kérdéseit igyekszem körbejárni, ezekre keresek válaszokat, az Ajánlás egyfajta preambulumaként bemutatva a szabályozással és annak céljaival kapcsolatos körülményeket.

\section{Az elektronikus közvetítői piac szabályozása önmagában a tevé-} kenység elismerését is jelenti.

Jelen cikk a piaci környezet minél teljesebb ismertetése érdekében személyes és az internetes felületen végzett biztosításközvetítői tevékenység összehasonlításával is foglalkozik, számba véve egyes szempontokat és jellegzetességeket, amelyek e két disztribúciós csatornát jellemzik, különös tekintettel a jellemzők közötti eltérésekre.

A cikk kifejezetten az - elektronikusan, illetve személyesen végzett független biztosításközvetítöi - alkuszi tevékenységre fókuszál, vagyis azon közvetítőkre, akik egy meglevő ügyféligényre keresik meg a leginkább adekvát biztosítási megoldást azzal, hogy beszerzik a biztosítók ajánlatait. A függő - vagyis a biztosítók megbízásából eljáró, adott élethelyzetre biztosítási megoldást kínáló - közvetítők tevékenységének elemzésére nem tér ki. Az alkuszi működés és annak szabályozása ugyanis a függő közvetítői tevékenységekkel (ügynök, többes ügynök) összevetve a legszélesebb tevékenységspektrumot öleli fel. Éppen ezért a tevékenység alkuszként történő végzése állítja talán a legjelentősebb kihívás elé a piaci szereplőket.

Az első részben az elektronikus kereskedelmi tevékenység térhódítása és ennek kapcsán az internetes fogyasztói magatartások, illetve azok változása kerülnek bemutatásra. Ezt követően az internetes vásárlással kapcsolatos döntés pszichológiájára is kitérve az internetes közvetítés elterjedése nyomán megjelenő, ott tapasztalt negatív jelenségeket veszem számba. A harmadik részben kerülnek meghatározásra azok a célok, indokok, amelyek az elektronikus közvetítés szabályozását, az Ajánlás megszületését indukálták. Ebben a részben arra is kitérek, miként esett a választás az adott szabályozási eszközre, a megválasztásának indokaival kapcsolatban az eszköz egyes jellegzetességeivel összefüggő megállapítások kerülnek kifejtésre. Végül az Ajánlás hatásainak egyes rendelkezéseinek a piaci szereplők körében történő teljesüléséről, annak az MNB általi visszaméréséről lesz szó, majd az utolsó rész az elektronikus közvetítéssel kapcsolatos fontosabb megállapítások összefoglalását és a jövőbeni terveket tartalmazza.

\section{I.2. Az internetes fogyasztói magatartások változása}

A fogyasztói szokásoknak az elmúlt évtizedekben tapasztalható átalakulásával az elektronikus vásárlások aránya évről évre növekszik. Korábban az alacsony internetes penetráció akadályozta az internetes vásárlás szélesebb körű elterjedését, a lakosság internetes hozzáférésének markáns növekedésével azonban az internetes vásárlások objektív akadálya is csökkent. 2014-ben a magyar háztartások 73 százaléka rendelkezett internet-hozzáféréssel, ennek csaknem teljes egésze (99\%-a) széles sávú volt, a keskeny sávú kapcsolat jelentéktelenné vált. Az internet és a széles sávú internet elterjedtségének tekintetében 8 , illetve 6 százalékponttal maradtunk el az uniós átlagtól (81, illetve 78\%), a különbség mindkét esetben csökkent a megelőző évhez képest. Az uniós tagállamok rangsorában hazánk az utolsó harmadba tartozik. 2015-ben az internet-hozzáféréssel rendelkezők aránya 75 százalékraํ növekedett. (1. ábra)

1. ábra: Internetpenetráció a közép- és kelet-európai régióban 2014-ben, 18-69 éves személyek körében

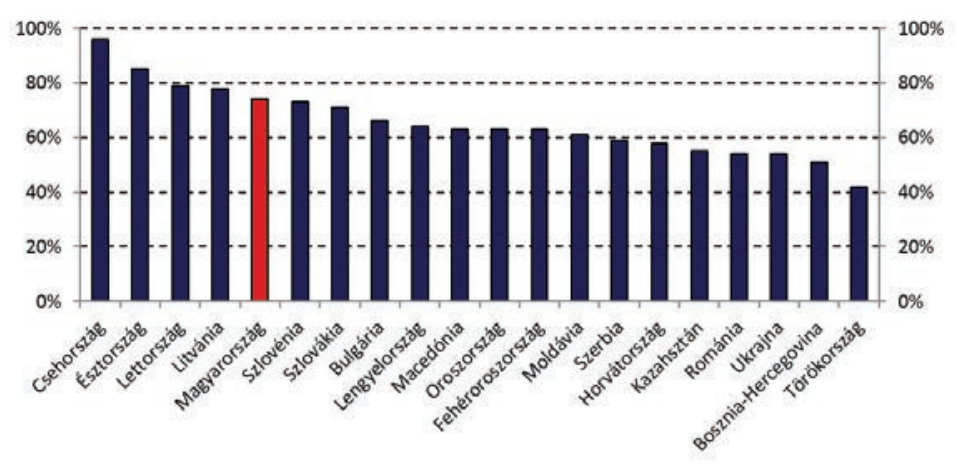

Forrás: Gemius/Ipsos 
A digitális lehetőségek fejlődése a fogyasztókban kialakította a felfedező jellegű online vásárlás képét. A Nielsen Holdings N.V. globális információs és piackutató vállalat stratégiai kezdeményezésekért felelős elnöke szerint „A fogyasztók mindenütt jó terméket akarnak jó áron, és a virtuális környezet látszólag korlátlan választéka új lehetöséget kínál kereskedöknek is, fogyasztóknak is"[1]. Vagyis a fogyasztók sokat nyerhetnek az internettel, nagyobb piacra léphetnek be, több szolgáltatóhoz nyernek hozzáférést, és választási lehetőségeik is kiszélesednek. Az internet korábban nem létező teret biztosít a termékek, eladók és árak összehasonlítására. Az Európai Unió fogyasztóvédelmi biztosának e-kereskedelem akadályairól szóló jelentése² szerint a fogyasztók általában elégedettek az online vásárlással.

\section{A magyarországi e-vásárlók preferenciái némileg eltérnek az Európában általánosan tapasztalttól.}

A különösen gyakran vásárolt - például az informatikai eszközök vagy a szórakoztató és szabadidős - termékek csoportjában az internetes vásárlásokkal kapcsolatos fogyasztói elégedettség átlagban magasabb, mint a kiskereskedelem más értékesítési csatornáin keresztül általában. A fogyasztók az árak összehasonlíthatóságát, a szélesebb választékot, a termékek elérhetőségét és az eladók közötti választás lehetöségét értékelik. Ugyanakkor problémának tekintik az egyértelmü termékismertetők hiányát, a kéretlen reklámokat, az adatvédelem hiányosságait, a megbízhatóság és az áruk visszaküldésének korlátozottságát ${ }^{3}$.

A magyarországi kutatások azt mutatják, hogy a magyarországi e-vásárlók preferenciái némileg eltérnek az Európában általánosan tapasztalttól, itt ugyanis elsősorban a kényelem (69\%), valamint a kedvező árak (54\%) miatt választják a vásárlásnak ezt a formáját, de nagyra értékelik a házhozszállítási, valamint ár-összehasonlítási lehetőséget is ${ }^{4}$. (2. ábra)

2. ábra: Magyarországi e-vásárlók preferenciái

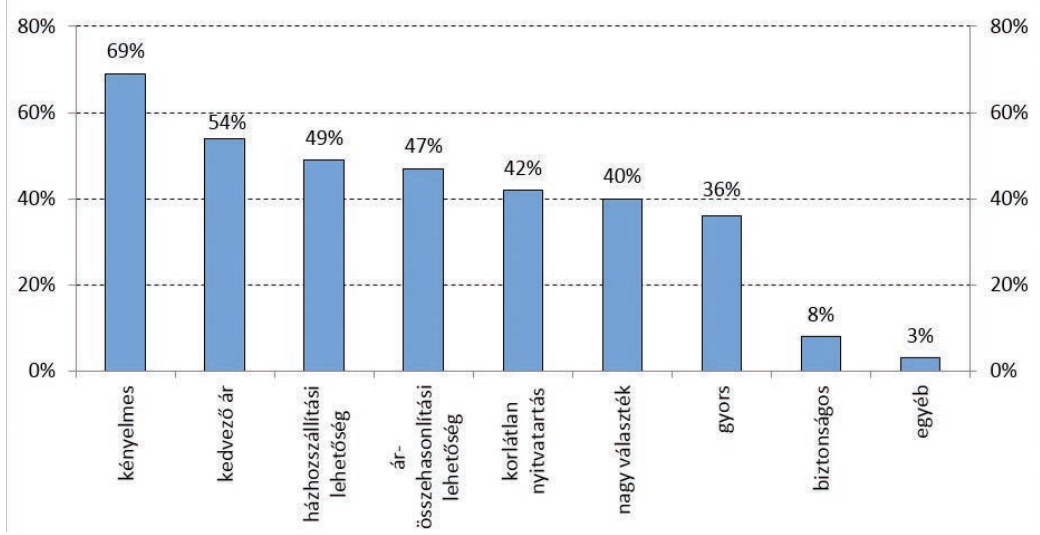

Forrás: e-NET.hu
Azok, akik egyáltalán nem vásároltak még online (rendszeresen internetező felnőttek 16\%-a), legtöbbször azt kifogásolták, hogy egyrészt nem tudják megfogni, megvizsgálni a terméket, másrészt pedig nem bíznak magában az internetes vásárlásban. A rendszeresen internetezők fele legalább negyedévente vásárol valamit az interneten, legtöbben számítástechnikai eszközöket, könyveket, játékokat/ajándékokat, valamint ruházati termékeket vesznek. A rendszeresen internetező, felnőtt online vásárlók a vásárlás során a legnagyobb arányban a termék árát (93\%), a szállítási díj mértékét (93\%) és a termékről elérhető képeket (92\%) tartották fontosnak ${ }^{5}$. A Mediascope 2012-ben végzett kutatásának adatai ${ }^{6}$ alapián az európai netezők 51 százaléka, a hazaiak 49 százaléka mondja, hogy az internet segítségére van abban, hogy jobb termékeket és szolgáltatásokat válasszon. A hazai internetezők számára az internet az elektronikai termékekkel (69\%), biztosítással (58\%), utazással (57\%), pénzügyi termékekkel, szolgáltatásokkal (55\%) és mobil készülékekkel, előfizetésekkel kapcsolatban (51\%) hozott vásárlási döntésekben a legfontosabb. Európában az utazási jegyek, elektronikai termékek, utazás és mobil készülékek, előfizetések állnak a toplista első öt helyén.

A tényleges internetes értékesités Magyarországon évrőlévre növekszik. A magyarországi internetes értékesítés 24 százalékos bővülése 2014-ben a legmagasabb volt a régióban és az uniós tagállamok között is? . Az európai átlagértékek most már lassuló növekedést mutatnak, a magyar e-kereskedelem növekedési száma az európai kontinens országai közül kiemelkedően magas értéket mutat, és soha nem látott progresszív növekedési tempót vetít előre a következő 2-3 évre.

Az e-kereskedelem hazai számait megnézve leginkább az e-vásárlók száma meglepő, 2014-ben 3,4 millió volt, beleértve a termékek és/vagy szolgáltatások megrendelőit is. (Ez a szám 2012-ben még csak 1,65 millió fö volt.) Az e-kereskedelem további fejlődése szempontjából az egyik legizgalmasabb kihívás a mobil eszközök terjedése és ezen felület megfelelő hasznosítása. A 3,4 millió online vásárlónak már 10 százaléka rendelt okostelefonról is, 4 százalék pedig táblagépről - azaz összesen közel félmillióan vannak azok, akik rendeléshez okoseszközeiket is használják.

\section{I.3. Elektronikus értékesítés a biztosítási szektorban}

Az e-kereskedem fejlődése, illetve a megváltozott (digitális kiszolgálást elváró) ügyféligények a biztosítási piacon is fejlődési folyamatot indukáltak. Az elmúlt néhány évtizedben bekövetkezett, a kereskedelem egyéb területein is jelentős hatást kifejtő üzemeltetési és technológiai változások új forgalmazási csatornák kifejlesztéséhez vezettek. Mindezek eredményeképpen a biztosítók már nem támaszkodhatnak kizárólag a hagyományos ügynöki és alkuszi csatornákra, ezért arra volt szükség, hogy maguk is olyan új alternatív csatornákat fejlesszenek ki, amelyek az újabb ügyfél-preferenciákra is figyelemmel alacsonyabb költségek mellett megörzik vagy növelik versenyképességüket. Mivel a verseny a biztosítási piacon is erősödik, a költségtakarékosság és a meglévő vevői kör megőrzése kritikussá vált, arra kényszerítve a biztosítókat, hogy olyan értékesítési módokat keressenek, amelyek az ügyfelek 
kényelmét szolgálják, a nyereség fenntartása és a költségek alacsony szinten tartása mellett. Ezen kihívásokra válaszul keletkeztek a call-centerek, mobil és webes alkalmazások, illetve egyéb IT megoldások. A digitalizácó térnyerésével azonban az informatika már nemcsak „megoldásszállító”, hanem „az üzlet része”, amely tételmondat a biztosító ügyfélkörének, termékválasztékának és értékesítési csatornáinak komplexitásával egyre igazabb lesz, vagyis a komplexitás növelésével az informatika egyre inkább az üzlet részévé válik ${ }^{8}$.

\section{Az informatika már nemcsak „megoldásszállító”,}

\section{hanem „az üzlet része”.}

A biztosítóknak a fenti folyamatok során arra is figyelmet kell fordítaniuk, hogy csökkentsék a direkt és a közvetítői csatorna közötti összeütközéseket, a többcsatornás (multichannel) értékesítési stratégia megtartása érdekében. A közvetítők ugyanis az európai trendek szerint országonként jelentős csatornamix-eltérésekkel, elsősorban a nem-élet szegmensben - stagnáló vagy enyhén csökkenő részesedése mellett továbbra is meghatározó szerepet játszanak a biztosítási szerződések közvetítésében. Az ügyfelek értékesítési csatorna választásáról általánosságban elmondható, hogy az optimális csatorna a különböző termékek és ügyféltípusok szerint változik, viszont az adott biztosítási piac nem feltétlenül igazodik az „optimális” csatornaválasztáshoz. Elsősorban azért, mert az ilyen „optimális” megoldás lehet átmeneti, másrészt ennél fontosabb tényezők az adott biztosítási piac történelmi fejlődése szerinti feltételek, valamint a szabályozási környezet változásai9

A változó piaci környezetben a biztosítókhoz hasonló kihívásokra kellett választ találniuk a közvetítőknek, azon belül az alkuszoknak is. A digitális fejlődés adta lehetőségek mellett a fogyasztói magatartások és a termékpreferenciák változása az elektronikus értékesítési csatorna és folyamatok katalizátora volt. A termék-összehasonlító oldalak a fenti fogyasztói preferenciákat vizsgálva éppen a fogyasztói igények közepébe találtak. Az ár-összehasonlítással a fogyasztók számára megtalálták a legkedvezőbb árú terméket, ugyanakkor megfeleltek azon új fogyasztói elvárásoknak, amelyek egyszerűséget, transzparenciát, gyorsaságot vártak el a terméket szolgáltatótól.

Ezért is lehettek annyira sikeresek az elektronikus biztosításközvetítők a hazai nem-életbiztosítási piacon a kötelező gépjármű-felelősségbiztosítási (kgfb) termék kapcsán az elmúlt évtizedekben. A kgfb termék paraméterei, viszonylagos egyszerüsége, tömegtermék jellege és kötelező volta alapján, megfelelően nagy vásárlói bázisa miatt kifejezetten alkalmas volt elektronikus értékesítésre. Ehhez jelentős tényezőkényt járult a január 1-jei évfordulóra koncentrált versenyhelyzet, valamint az, hogy a fogyasztók nagy tömegei váltottak egyszerre, amit a piaci szereplők intenzív marketingkampánnyal támogattak. A fogyasztói döntéseket szinte kizárólagosan a termék ára irányította. Ez a jellemző mind a mai napig megmaradt, ugyanakkor a fogyasztói döntésekhez időközben más szempontok is - így megbízhatóság, kényelem - vegyültek. A kgfb az elektronikus közvetítői értékesítés sikerterméke lett. 2010-ig nőtt, ekkor 1,3 milliónál tetőzött az évfordulókor neten váltók száma. A 2010-ben hatályba lépett jogszabály- változás - amely a biztosítási évfordulót nem a naptári évhez, hanem a szerződéskötés napjához igazította - hatására csökkent az évfordulókor neten váltók száma, 2013-ban már csak 435 ezer váltóról számolt be a MABISZ10 ${ }^{10}$ Jelenleg a közvetítők által közvetített kgfb-szerződések 39,7 százalékát a 3 legnagyobb elektronikus alkusz értékesítette 2014-ben, jelezve a kgfb-piacon az elektronikus közvetítői dominanciát ${ }^{11}$.

A magas kgfb-piaci részesedés mellett a teljes nem-élet szegmensben a top 3 jutalékbevétele nem meghatározó, a piaci jutalékbevételek 15 százaléka (csökkenő trend), ezzel mutatva, hogy a kgfb-n kívüli termékcsoportok esetében nagyobb tér mutatkozik a fejlődésre. ( 3. ábra)

3. ábra: A top 3 elektronikus közvetítő részesedése a nem-élet jutalékbevételekbő

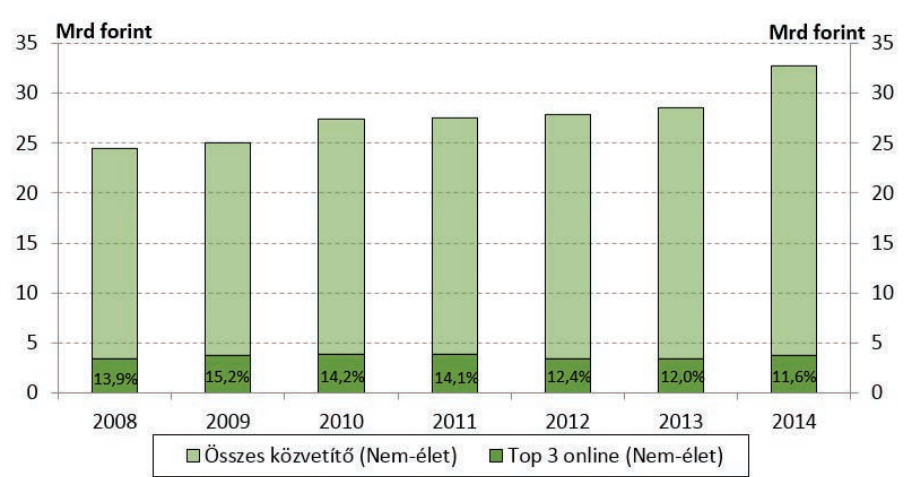

Forrás: $M N B$

A kgfb terméken túl ma már más biztosítási ágazatokban - elsősorban casco, lakás-, illetve utasbiztosítások területén - is láthatóan elindult az elektronikus közvetítés. Ezenkívül más termékszegmensekben - így például életbiztosítási területen - is zajlik az útkeresés. (4. ábra)

4. ábra: A top 3 elektronikus közvetítő termékértékesítésének megoszlása 2014-ben (darab)

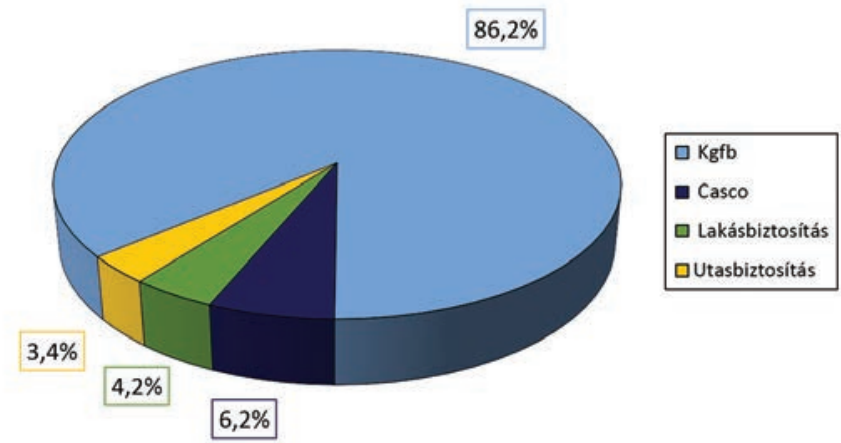

Forrás: $M N B$ 
A korábban az értékesítés egyik eszközeként használt elektronikus platform így már nemcsak a kgfb termék vonatkozásában vette át a tényleges közvetítői feladatokat, hanem egyre több terméknél. Ezt a jelenséget természetesen úgy is lehet nézni, hogy a korábban kizárólag kgfb termékek közvetítésére szakosodott elektronikus közvetítők egyre szélesebb termékkört kezdtek el közvetíteni, tevékenységüket kibővítették. A végeredmény ugyanaz, sok szempontból teljes közvetítői feladatokat ellátó elektronikus felület, az elektronikus közvetítő,

\section{Az összehasonlító honlapok által végzett tevékenység \\ társadalmilag hasznos.}

Az elektronikus közvetítők, összehasonlító honlapok által végzett tevékenység több szempontból is hasznos társadalmilag, növeli a versenyt a biztosítók között, ami segíti az átláthatóságot, és a termékek összehasonlításával növeli a fogyasztók rendelkezésére álló információk körét. Ezen túl - a személyeshez hasonlóan - az elektronikusan végzett közvetítői, alkuszi tevékenységnek nemcsak valamely termék, szolgáltatás egyszerü közvetítése, értékesítése a feladata, hanem hozzáadott értékként az ügyfeleknek leginkább megfelelő termék megtalálását és ezzel az ügyfél kockázatának - a biztosítók által kínált termékek jellemzői szabta keretek között - személyre szabott kezelését is jelenti. Mindez pedig a csatorna sajátosságai miatt a folyamat ügyfél általi nyomon követhetőségével párosul. Az alkusz a megbízó képviseletében jogosult a szerződés megkötésére, a megbízó igényeinek érvényesítésében történő közreműködésre, az ügyfél tájékoztatása alapján pontosítja az ügyfél igényeit és szükségleteit, valamint azokat az indokokat, amelyek a biztosítási termékkel összefüggésben adott szaktanácsot alátámasztják. Az alkusz ezen kötelezettségei lényegüket tekintve az új biztosítási törvény alatt sem módosultak. Jó esetben egyfajta, az ügyvédi megbízáshoz hasonló bizalmi viszony épül ki a közvetító és az ügyfél között.

Az elektronikus felületen azonban ez a perszonális viszonyátalakul, személytelenné válik. A bizalmi viszony kialakulása helyett a lényegi elem már nem a közvetítő személyén keresztüli direkt tanácsadás, hanem a minél teljesebb információszűrés, információátadás válik elsődleges jelentőségűvé az ügyfél számára. Arra azonban továbbra is szükséges figyelni, hogy az információátadás csak annyiban lesz eredményes, amennyiben az ügyfél a személyes interakcióhoz hasonló, prompt és szakszerű, mégis érthető válaszokat kap. A felület kialakításánál figyelemmel kell lenni arra, hogy az az értékesítési szituációhoz, beszélgetéshez hasonlóan a termék megértését segítse, kellőképpen általános, egyszerűen érthető tudjon maradni, de adott kérdés esetén részletezett tartalmú, mélyebb kidolgozottságú válaszokat is tudjon adni.

\section{I.4. Az internetes vásárlással kapcsolatos döntés pszichológiája}

A fogyasztók számára az internet döntés-előkészítő, döntéstámogató eszközzé vált a vásárlásokban: ma már egyértelmű, hogy rengeteg termék, szolgáltatás vásárlása előtt átnézzük, mit írnak róla, hol lehet megvásárolni. (5. ábra)
5. ábra: Online végzett tevékenységek aránya 2014-2015

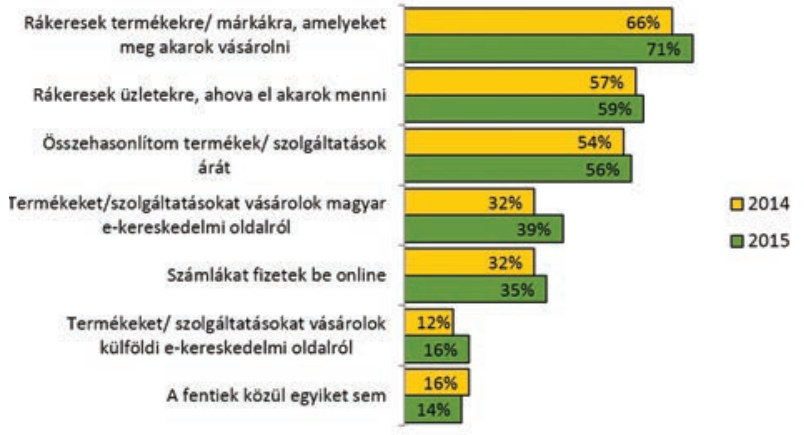

Forrás: gemius.hu, e-commerce riport 2015)

Az interneten a felhasználó, az ügyfél az első, és az interneten ingyenessége révén sok esetben ő maga a termék: a figyelme, a befolyásolhatósága. Mindezek miatt az online vásárlás kapcsán fontos foglalkozni a vásárlói döntések pszichológiájával is. Azzal, hogy hogyan gondolkodnak a vásárlók, mi motiválja őket, amikor döntést hoznak egy-egy termék vagy szolgáltatás megvásárlásakor, illetve ezen döntési helyzetben milyen technikákkal tudnak befolyást gyakorolni az értékesítők.

Az egyéni vásárlói döntés folyamatában a vásárlási döntést egyidejűleg sok külső és belső tényező befolyásolja ${ }^{12}$. (1. táblázat)

1. táblázat: Vásárlási döntést befolyásoló tényezők

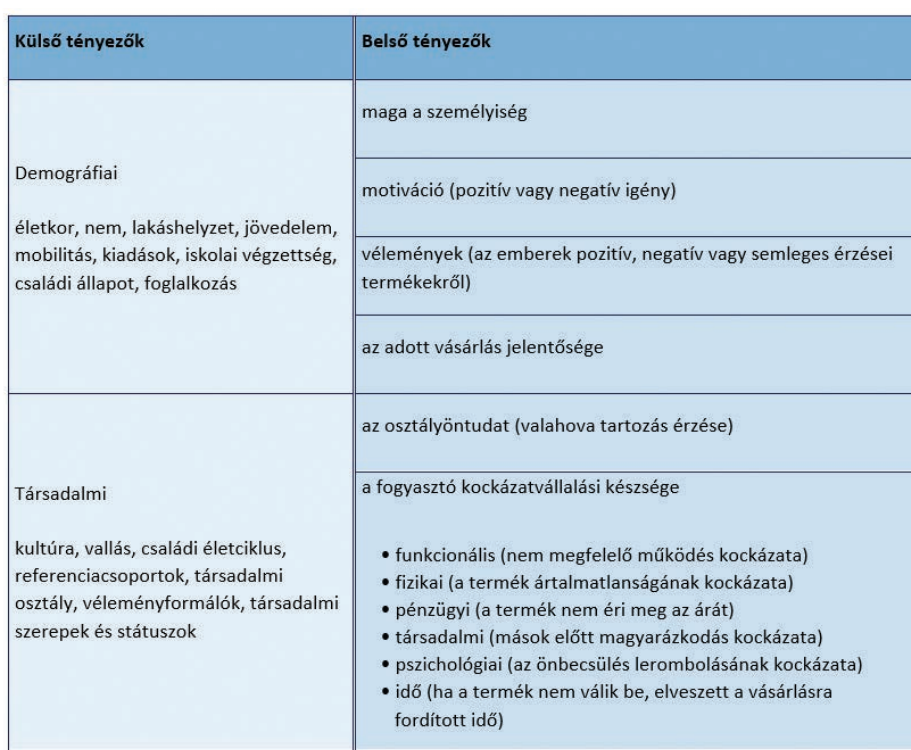

Forrás: Dr. Mészáros Katalin: Marketing 
A döntések mérlegelésében, meghozatalában egyre inkább részt akarnak venni az értékesítők, a megfelelő technikákkal a döntés folyamatában is egyre jelentősebb szerepet tudnak játszani, adott esetben befolyásolni a fogyasztói döntést. A legismertebb befolyásolási technika a reklám, amely hatásos az információgyűjtés és a vásárlási döntés szakaszában is. A termékröl, a termék közvetítőjéről szóló hír, cikk, a terméket kedvező színben bemutató médiamegjelenés, vagyis a propaganda, illetve a mindenki által ismert vásárlásösztönzési technikák (árengedmények, jutalmak, díjak, ingyenes szolgáltatások, kuponok) szintén alkalmasak a vásárlási döntés befolyásolására.

Nagyban befolyásolja a vásárlók döntését az is, hogy a többi ember hogyan döntött hasonló helyzetben. Ha az adott webáruházban látható, hogy az adott terméket hányan vásárolták már meg vagy ajánlották vásárlásra, akkor ezzel az aktuális látogató is vásárlásra ösztönözhető. Mindez arra a felismerésre épül, hogy a bizonytalan helyzetben mások véleménye meghatározó lehet. Különösen igaz ez, ha az adott terméket valamely ismert, meghatározó személyiség ajánlja. További eszköz lehet az igénykeltés. Kutatások megerősítették, hogy ha valami csak korlátozott ideig vagy korlátozott számban elérhető, akkor nagyobb igény keletkezik rá, mintha ezek a korlátozások nem lennének. A fenti két alapelv alkalmazása hatékony konverziónövelő eszköz lehet, és rengeteg optimalizálási lehetőséget kínál. Az online vásárlások esetén ugyanakkor ezen eszközöknél is elmondható, könnyủ velük visszaélni is, így ezek alkalmazása a fogyasztói döntések tisztességtelen befolyásolására is vezethet ${ }^{13}$.

\section{I.5. Negatív jelenségek az elektronikus közvetítésben}

Az elektronikus biztosításközvetítők fejlődésével, jelentős piaci térnyerésével, az egyes korábban említett eszközök egyre tudatosabb használatával együtt megfigyelhetők olyan jelenségek is, amelyek adott esetben a fogyasztókkal szemben tisztességtelennek, jogsértönek minősültek. Ezen jelenségek, azon túl, hogy az adott esetben kárt okoztak az online ügyfeleknek, a biztosítási piacnak is ártottak, mivel a rossz tapasztalat miatt ezen ügyfelek kisebb valószínűséggel fogják ezt az értékesítési csatornát választani a jövőben biztosításuk megkötésére. Különösen hátrányos lehet az ügyfélre és ezen keresztül a piacra nézve az, ha az adott gyakorlatot már a piac több szereplöje is alkalmazza, így a fogyasztó egyre kevésbé tudja elkerülni az adott, számára hátrányos eljárási megoldást.

Az Europe Economics által Európa több országára kiterjedően végzett kutatás alapján ilyen, kifejezetten az (elektronikus) összehasonlító oldalak által alkalmazott rossz megoldás, ha a termékek vagy szolgáltatók listázása, a lista sorrendje nem objektív szempont alapján történik, hanem azt valamely módon befolyásolja a lista készítője, és ezt a szempontot nem teszi a fogyasztó számára nyilvánvalóvá. Amennyiben az adott szempont nyilvánvaló és egyértelmű, objektív, úgy a listázás nem jelent problémát, sőt, adott esetben segíti a fogyasztót a saját szempontrendszerének megfelelő preferencia megtalálásában. Az eltérő biztosítói jutalékozás miatt a közvetítő az összehasonlítás esetében előnyben részesíthet egyes termékeket. Szintén torzíthatja az összehasonlítás eredményét, ha az összehasonlítást végző közvetítő nem rendelke- zik a piac teljes kínálatával. A kutatás megállapította, hogy minél kevésbé átfogó lefedettséggel rendelkezik az adott közvetítő, az azt használó fogyasztók annál rosszabbul járnak. Ezenkívül a fogyasztók érdekeit sérti, ha a fogyasztók úgy hiszik, hogy az összes termék listázásra került, így abban a téves feltevésben veszik meg a terméket, hogy a piacon elérhető legolcsóbbat vagy az igényeiknek leginkább megfelelőt vásárolták meg.

Olyan gyakorlatok is azonositásra kerültek, amelyek nem elektronikus csatorna specifikusak, vagyis a tradicionális értesítési csatornákat is érintik. Egyértelműen problémát jelent mindkét csatorna esetében az, ha az összehasonlítást végző független közvetítőnek biztosító a tulajdonosa. Ez nyilvánvalóan összeférhetetlen, az ilyen tulajdonossal rendelkezö közvetítő ugyanis valószínűsíthetően részrehajló lesz a tulajdonos biztosító termékével kapcsolatban. A biztosítói jutalékok miatti érdekütközés természetesen a tradicionális értékesítési csatornákat is éppen úgy érinti, mint az elektronikus közvetítőket ${ }^{14}$.

\section{Rossz megoldás, ha a termékek vagy szolgáltatók listázása nem objektív szempont alapján történik.}

Az összehasonlító weboldalakkal kapcsolatban az EIOPA az összehasonlító weboldalak jó gyakorlatairól készített jelentésében is megfogalmazott néhány olyan jelenséget, amelyek negatívan befolyásolhatják az ügyfelek döntését ${ }^{15}$. Ilyen problémaként került azonosításra az, ha:

- a fogyasztók túlzottan az árra koncentrálnak, az adott termék egyéb paraméterei helyett;

- $\quad$ a közvetítők félrevezető információkat adnak az ügyfeleknek egyéb biztosítókkal fennálló üzleti érdekeltségük miatt;

- az összehasonlító oldalak nem szükségképpen alkalmasak minden biztosítástípus összehasonlítására, így például az életbiztosítási szerződések esetében az átlagos, ilyen oldalakon használt kérdéssorral megszerezhetőnél több információra van szükség.

Amint a fentiekben látjuk, az utóbbi években az európai színtéren számos probléma került azonosításra a biztosításközvetítői elektronikus piacon, és ezek némelyike a hazai piaci szereplőknél is megjelent. Mindezen folyamatokkal párhuzamosan az MNB tervezett, illetve eseti jelleggel, felügyeleti vizsgálatok sorát hajtotta végre az utóbbi három évben a közvetítői szektorban. A vizsgálatok az egyes formális követelmények (alapvető működési feltételek megfelelősége: adatszolgáltatás, tőkekövetelmény, bejelentési kötelezettségek teljesítése, felelősségbiztosítás, tevékenységirányító megléte) ellenőrzésén túllépve, egyre szélesebb körű és részletesebb, tartalmi elvárásokra is kiterjedtek (nyilvántartási rendszer, adatvédelem, regiszter), és egyre többször voltak alanyai a biztosítási piacon egyre meghatározóbb jelentőségű elektronikus közvetítők. Az ellenőrzések során a közvetítők fogyasztókat érintő eljárásainak szakmai és fogyasztóvédelmi szempontú vizsgálata került fókuszba, azzal a céllal, hogy a közvetítői piac ténylegesen a professzionális (magas fokú szakmaiságot mutató) és ügyfélbarát szolgáltatás irányába fejlődjön tovább. 
A vizsgálatok eredményei - az európai megállapításokkal részben összhangban - több problémát is feltártak az elektronikus alkuszoknál. Így jelentős problémaként került azonosításra, hogy nehezen elérhető vagy nem teljes körű a tájékoztatás egyes lényeges információkról, és egyes esetekben félrevezetőek, pontatlanok, nem naprakészek a felületetek. Ezzel kapcsolatban érdemes megjegyezni, hogy a félrevezetö, pontatlan információk közé tartozik az is, ha az alapvető információk nehezen elérhetőek az üzemeltetőről, illetőleg ha nem teljes körű a tájékoztatás ezen adatokról. Problémaként merült fel továbbá, hogy az ajánlatok összehasonlítása során - az európai felmérésben tapasztaltakhoz hasonlóan - nem mindig volt objektív a termékek sorrendje. Egyes esetekben hiányzott a megfelelö alkuszi megbízás, továbbá megállapítható volt az is, hogy sérült az alkuszi függetlenség. Ez utóbbi, összeférhetetlenségi, érdek-összeütközési probléma, az ügyfélnek jelentős sérelmet okozhat, kezdve a kisebb vagyoni hátránytól (drágább termék ajánlása) egészen a misselling-ig (ahol nem az ügyfél igényeinek megfelelő biztosítási terméket ajánl a közvetítő). A kérdés megoldására keresett választ az IMD 1.5 is (a MIFID II. direktíva 91. szakaszában kapott felhatalmazó rendelkezés alapján), amely ügyfél-, illetve biztosításközvetítői érdekkonfliktusok feloldása érdekében fogalmazott meg lehetséges válaszokat. Ezen megoldások jó része beépült a 2016. február 22. napián hatályba lépett, a biztosítási értékesítésről szóló 2016/97 irányelvbe (IDD), illetve egyes elemek várhatóan megjelennek majd az irányelv felhatalmazó rendelkezése alapján készülő második szintű szabályozásban is.

\section{Az ügyfél valós igényeinek megfelelő felmérése az elektronikus} feliiletek egyik legnehezebb kihívása.

Az érdekkonfliktusok megfelelő kezelésén túl, az értékesítési csatorna jellegétől függetlenül, az igényfelmérés az alkuszi működés másik lényeges sarokpontja. Az ügyfél valós igényeinek megfelelő felmérése a biztositásértékesítés, egyben az elektronikus felületek egyik legnehezebb kihívása, amely sok esetben, föleg ha sokféle termék közül lehet választani, meglehetösen nehezen végezhető el megfelelő szinten. E tekintetben az elvárt kiindulópont, hogy az elektronikus alkusznak legalább a személyes közvetítéssel azonos színvonalon kell végeznie az igényfelmérést, a kiválasztásban történő tanácsadást. Ezt az elvi megközelítést erősíti az EIOPA véleményében megfogalmazott álláspontja is, miszerint az, hogy a közvetítő a tevékenységét elektronikusan végzi, nem szabad, hogy befolyásolja a tevékenységre vonatkozó szabályozásnak történő megfelelését ${ }^{17}$. Ezt támasztja alá a közvetítés ezen módjára vonatkozó hazai jogi szabályozás is.

\section{I.6. Az elektronikus közvetítés szabályozása}

A hazai biztosításközvetítői szabályozás - az uniós előírásokkal összhangban - meglehetősen tágan határozza meg azt, hogy mi tartozik a biztosításközvetítés fogalmába. A biztosítási tevékenységről szóló 2014. évi LXXXVIII. törvény 4. \$ (1) 14. pontja alapján biztosításközvetítői tevékenység: a biztosítási szerződés létrehozására irányuló üzletszerű tevékenység, amely kiterjed a biztosítási szerződések megkötésének elősegítésére, biztosítási termékek ismertetésére, ajánlására, az ezzel kapcsolatos felvilágosításra, a biztosítási szerződések megkötésére, a biztosítási szerződések értékesítésének szervezésére, továbbá a biztosítási szerződések lebonyolításában és teljesítésében való közremüködésre.

A fogalom meghatározása láthatóan nem tér ki arra, hogy a tevékenység végzése milyen módon és milyen eszközzel történhet. Ebből azt az elvszerü következtetést lehet levonni, hogy a jogalkotó a közvetítés módjára, a használt eszközre tekintet nélkül ugyanazon szabályozást rendeli használni. Vagyis a Bit. jelenlegi szabályozása alkalmazandó a személyesen, illetve az elektronikus felületek segítségével végzett tevékenységre egyaránt. Az egyes rendelkezéseket megvizsgálva azt láthatjuk, hogy azok a közvetítés általános kereteiről rendelkeznek, külön szabályokat nem tartalmaznak az elektronikus közvetítői, értékesítési tevékenységre vonatkozóan.

Az eredetileg személyes értékesítésre létrehozott szabályozás egyes rendelkezéseinek elektronikus felületekre történő alkalmazási módja adott esetekben kérdéseket vethet fel. Megjegyzendő, hogy a biztosítási törvény csupán egy helyen említ személyes eljárási kötelezettséget, mégpedig - ügyféligény esetén - a biztosításközvetítő panaszkezelésére vonatkozóan. A jelenlegi szabályozásról az azonban mindenképp elmondható, hogy bizonyosfajta fogyasztóvédelmi alapelveket már most megfelelően érvényesít, amelyek érvényesülése alapkövetelmény, tekintet nélkül arra, hogy a közvetítési tevékenység személyesen vagy elektronikus úton valósul-e meg. Ezen túlmenően lehet abban gondolkodni, hogy mely eljárásokat szükséges aktualizálni az elektronikus felületekre vonatkozóan.

\section{Az ajánlásról röviden}

\section{Elektronikus közvetítéssel kapcsolatos Ajánlás}

A biztosításközvetítés ezen, rendkívüli dinamikával változó, speciális területének szabályozási igényét a fentiekben részletezett körülmények együttesen indukálták. Ténylegesen tehát az, hogy - mind a termékek, mind az elektronikus felületek, mind az eszközök (táblagép, mobil) tekintetében - a növekvő biztosításközvetítési volumennel együtt járt, hogy ezen értékesítési csatornán is megjelentek, illetőleg a kiterjedtebb tartalmi vizsgálatok miatt fókuszba kerültek egyes nemkívánatos, esetenként jogsértő jelenségek, amelyekre a jogi környezet kifejezetten nem adott választ.

A jogi környezet változatlansága ugyanis nyitva hagyott olyan kérdéseket, amelyek fogyasztóvédelmi és szakmai szempontból nem maradhattak válasz nélkül annak érdekében, hogy a megfelelö mederben folytatódjon, fejlődjön az elektronikus értékesítés. Ezen kérdések egyértelmű megválaszolása mentén lehetséges ugyanis kijelölni azt az utat, azon működési eljárásokat, amelyek az elektronikus közvetítői müködést ügyfélbaráttá teszik, segítik az ügyfelek igényének kielégítését az elektronikus felületeken. A válaszok, illetőleg az irányok a fentiekben hivatkozott vizsgálatok tapasztalatai alapján, illetve az elektronikus közvetítői piac szereplőivel, az érdek- 
képviseleti szervekkel (FBAMSZ, MABIASZ, MABISZ), valamint a szakágazati jogalkotóval (NGM) folytatott párbeszéd, véleményezés, illetve nyilvános konzultáció folyamán érlelődtek ki. Az érdekképviseletekkel való együttműködés kifejezetten hasznos javaslatokkal, felvetésekkel javította, tette adott esetben életszerűbbé, pragmatikusabbá az Ajánlás tartalmát. Ugyanígy a piac észrevételeit is igyekezett figyelembe venni az MNB, ahol lehetett, illetve - amennyiben a javaslat szerinti irányt az MNB megfelelőnek, elöremutatónak találta - beépíteni.

Annak érdekében, hogy az egyes piaci szereplők ugyanazt a tartalmat értsék az egyes - nem kifejezetten elektronikus közvetítőkre vonatkozó - jogszabályi rendelkezéseken, az elektronikus közvetítők vonatkozásában, az egyértelműség és a jogalkalmazás kiszámíthatóságának növelése érdekében szükség volt egyfajta közös értelmezésre. Az Ajánlás előkészítése során ilyen értelmezési kérdés, feladat volt már maga az elektronikus közvetítés fogalmának tisztázása és a tevékenységhez kapcsolódó egyéb fogalmak egyértelmű meghatározása, illetve az egyéb elektronikusan végzett tevékenységektől történő elhatárolása is.

Önmagában az elektronikus közvetítői tevékenység, illetve a tevékenység egyes eljárásainak újszerűsége miatt nehézséget jelentett az egyes piaci megoldások, gyakorlatok, kategóriák szerinti azonosítása, ezekhez kockázati térképek készítése, a lehetséges problémák feltárása. Ezen egyértelműsítések, piaci kategóriák kimunkálásából vették ki a részüket a piac képviselöi, illetve az érdekképviseletek is. Az eltérő funkciójú elektronikus felületek azonosítása kapcsán lényeges kérdésként merült fel az Ajánlás hatályának kérdése. Ebben az esetben az MNB úgy látta megfelelőnek, ha a szabályozás hatályát minél szélesebb körben határozza meg, annak érdekében, hogy az alapvető, minimális követelmények minden elektronikus felületet használóra kiterjedjenek. Így az Ajánlás hatálya nemcsak a jól ismert elektronikus közvetítői oldalakra, hanem az ügyfelek, illetve a közvetítők számára elérhető minden internetes oldalra, online, illetve offline számítógépes vagy mobil alkalmazásra is kiterjed, amely a biztosítási termékek általános ismertetését, ajánlását és az azzal kapcsolatos felvilágosítást szolgálja, valamint ezen elektronikus felületek müködését támogató szolgáltatókra is (pl.: platformfejlesztők). Alkalmazandó azon oldalakra is, amelyek különböző cikkek, írások segítségével keltik fel az ügyféligényt biztosítások megkötésére, adott esetben lehetőséget biztosítva az érdeklődő ügyfelek személyes értékesítőhöz vagy értékesítési felületre történő továbbítására. Az Ajánlás a hatálya alá tartozó szervezeteknek, felhasználóbarát módon, strukturáltan mutatja be, hogy mely értékesítési felületre mely elvárások, rendelkezések vonatkoznak.

Az MNB az Ajánlásával az ügyfelek számára átláthatóbb, funkciójukban az ügyféligényekhez jobban illeszkedő elektronikus felületek fejlődését kívánja előremozdítani a biztosítási piacon. Az elektronikus közvetítők kgfb termék értékesítése esetében korábban tapasztalt, elsődlegesen áralapú összehasonlítását szükségesnek látja fejleszteni. Az MNB az Ajánlásban elvárja, hogy a biztosítási szerződések az ügyfél által egyénileg megválasztható szempontrendszer figyelembevételével a biztosítási fedezetek és szolgáltatások (pl. önrész, biztosítási összegek, kiegészítő fedezetek, mentesülések, kizárások, többletszolgáltatások) alapján is összehasonlíthatóak legyenek.

Az MNB jó gyakorlatnak tartja, ha a biztosítást értékesítő utólag felméri az ügyfeleknek a választott szerződéssel kapcsolatos elégedettségét, különös tekintettel a szolgáltatás teljesítésével - különösen a kárrendezéssel - összefüggö tapasztalatait. Mindezzel az árverseny mellett megvalósulhat a szolgáltatások színvonalának versenye.

Az MNB az Ajánlásával korábban tapasztalt, elsődlegesen áralapú összehasonlítását szüikségesnek látja fejleszteni.

Az Ajánlásban is megjelenő alapvető elvárás, hogy az elektronikus felületen megjelenő írások, cikkek érthető, alapos, szakmailag korrekt tájékoztatást adjanak, fókuszálva az ügyfelek számára releváns tényekre, információra. Az MNB elvárja, hogy az elektronikus felület által alkalmazott kommunikáció ne tartalmazzon félrevezető vagy félreérthető információt, olyan feltételezéseket, amelyek a pénzügyi közvetítőrendszerbe vagy annak egyes részeibe vetett közbizalom gyengítésére alkalmasak, illetve azt eredményezhetik.

Ilyen jelenség lehet a megtévesztő, valótlan állítások alkalmazása, illetve a különböző szektorális termékek nem megjelenített, szűrt szempont szerinti összehasonlítása, mely így nem objektív eredményt mutat. Jó gyakorlat, ha az elektronikus felületen közérthető és magas szakmai színvonalat képviselő szakcikkek jelennek meg, ugyanakkor szükséges, hogy a szerző saját véleménye egyértelműen különüljön el a szakmai tényektől.

Kiemelten fontos, alapelvi szinten is megjelenő elvárás, hogy az ügyfél az elektronikus felületen a valós igényeihez és szükségleteihez ténylegesen igazodó biztosítási szerződést köthessen, úgy, hogy a biztosítás értékesítője betartja a jogszabályokban elöírt tájékoztatási és tanácsadási kötelezettségét, ezzel elkerülve a nem kívánt szerződéskötést és félreértékesítést. Az igényfelmérés mélységét az ügyfél körülményei és biztosítási igényei, illetve a termék sajátosságai, komplexitása határozzák meg. Kerülendő az a gyakorlat, hogy az értékesítő néhány fő adat bekérése alapján (egy vagy több releváns adat hiányában) a „legjobb” ajánlatként jelöli meg valamely szolgáltató termékét.

Az MNB elektronikus közvetítéshez kapcsolódó szabályozása, a szabályozás kihívásainak megoldása úttörő jellegü, erre a területre vonatkozóan ugyanis semmilyen iránymutatásul használható közös európai vagy akár tagállami megoldás nem létezett korábban. A szabályozási igény már egyes, fejlett elektronikus közvetítői piaccal rendelkező tagállamokban is megfogalmazódott (Anglia, Olaszország), illetve az EIOPA adott ki javaslatot és jelentést ezen témakörhöz kapcsolódóan, valamint az Európai Unió is szabályozási céllal - jelenleg nyilvános konzultációt folytat az elektronikus közvetítőkkel kapcsolatban ${ }^{18}$. Feltehetőleg mindezek fényében az EIOPA elnöke, Gabriel Bernardino kifejezetten üdvözölte és határozottan támogatta az MNB által kiadott Ajánlást, mint olyan 
kezdeményezést, amely a fogyasztóvédelmi szabályozás előmozdítása mellett elősegíti az elektronikus biztosítás értékesítésével kapcsolatos innovációkat. Örömmel vette, hogy az Ajánlás több, az EIOPA által kiadott ajánlást és dokumentumot felhasznált, és reményét fejezte ki, hogy az EIOPA küszöbön álló kiadványai (Digital selling platforms; Automated financial advice tools) segíthetik majd az MNB-t az Ajánlás továbbfejlesztésében.

Az Ajánlás az EIOPA által hivatkozott funkciókat is (fogyasztóvédelem, innováció) hivatott betölteni, olyan módon, hogy az egyértelmüsítéseken túl ismertetésre kerülhetnek az MNB által alkalmazni javasolt elvek, módszerek is.

A piaci igények és az azokra adott megoldások gyors változása, dinamizmusa és a több hasonlóan megfelelő megoldás miatt a jogszabályi formában történő szabályozás azonban ezen a gyorsan változó, innovatív piacon nem feltétlenül a legalkalmasabb. Az ajánlás mint szabályozó eszköz rugalmassága, alakíthatósága és orientáló jellege miatt sokkal jobban megfelelt az MNB ezen piacon elérni tervezett, fentiekben hivatkozott céljainak. A kívánt hatás elérése érdekében az MNB az ajánlásban meghatározottak betartását, alkalmazását helyszíni és helyszínen kívüli vizsgálatok során ténylegesen vizsgálja és értékeli.

Emellett az Ajánlás révén az MNB olyan speciális, nagy részletezettségű iránymutatásokat tud adni az elektronikus közvetítők számára, amelyek mind az általános keretjellegü jogszabályi, mind az ügyfelek elvárásainak megfelelnek. Így az MNB elképzelése szerint az alapos, szakszerű, a közvetített biztosítási szolgáltatás sajátosságához illeszkedő tanácsadás mellett alapvető fontosságú az, hogy a fogyasztók a biztosítási szolgáltatások árán túl azok tartalmáról is könnyen áttekinthető és értelmezhető összehasonlítást kapjanak az igényeiknek leginkább megfelelő termék kiválasztásához. Meghatározásra kerülhettek továbbá az elektronikus felület minimális tartalmával, funkciójával, átláthatóságával, felhasználhatóságával és kielégítő működésével, az ügyfelek tájékoztatásával szembeni elvárások. Emellett olyan nagy kihívást jelentő kötelezettséggel kapcsolatban is iránymutatást nyújt az Ajánlás, hogy az ügyfél biztosítási igényeinek és szükségleteinek felmérését miként látja az MNB megfelelőnek.

Az MNB célja az Ajánlás módszeres továbbfejlesztése a legjobb piaci gyakorlatok beépítésével.

Mindezek alapján az Ajánlásra nemcsak egy újabb kötelezettségként lehet tekinteni, hanem mint olyan, a piac legjobb technikáit tartalmazó csomagra, amelynek segítségével az adott közvetítö is ügyfélbarátabbá teheti eljárását, és tevékenységében is sikeresebb lehet az abban foglaltak folyamataiba történő beépítésével. Mindezen célok elérése érdekében, illetve azért, hogy a közvetítők a piacon elérhető, a fogyasztók számára legjobb szolgáltatást nyújtsák, az MNB célja az Ajánlás módszeres továbbfejlesztése, az adott időszakban elérhető legjobb piaci gyakorlatok beépítésével.

\section{Az ajánlás hatása, visszamérése}

\section{Az elektronikus Ajánlás visszaméréséről}

Az Ajánlásban foglalt fogyasztói érdekek minél teljesebb érvényesítése, az alkalmazni javasolt elvek, módszerek ismertetése és az online közvetítési gyakorlat ez irányú elmozdítása érdekében az MNB fontosnak tartotta az Ajánlásban foglaltak teljesülésének minél teljesebb körben történő visszamérését. Ezért egyes intézményeket érintően önvizsgálat-alapú módszerrel, valamint célvizsgálatok keretében méri az Ajánlásban foglaltaknak történő megfelelést.

Az MNB az Ajánlás hatálya alá tartozó kiválasztott biztosításközvetítőktől, egyes biztosítóktól, valamint e-felületet fejlesztőktől kérte az általa készített kérdőív kitöltését. A megkeresett intézmények együttműködtek, a visszaküldött kérdőívek alapján a teljesség igénye nélkül az alábbi megállapítások tehetők:

Mindenekelőtt az intézménytípusok alapján általánosságban megállapítható, hogy a biztosítói oldalak nem hasonlítanak össze termékeket, így az Ajánlás által szabályozni hivatott jelentős területet érintő kérdésre „nem értelmezheto”” választ adtak, azonban a jogszabályi elvárásoknak az e-felületük általánosságban a korábbiakban is megfelelt.

Az Ajánlás kapcsán a legjelentősebb változások leginkább a közvetítők esetén érhetőek tetten. A közvetítők esetében kiemelendő, hogy az Ajánlás hatására példaértékű folyamatokat láttunk megindulni. Egyre több közvetítő elektronikus felületén már nem kizárólag az ár alapján, hanem a nyújtott szolgáltatások szerint is összehasonlíthatóak a biztosítások. Új, az MNB Ajánlásban foglalt jó gyakorlatok jelentek meg az elektronikus felületeken, így megjelenítésre kerültek az ügyfelek választott szerződéssel kapcsolatos elégedettségével - különös tekintettel a szolgáltatás teljesítésével, egyebek mellett a kárrendezéssel - összefüggő tapasztalatai. Az ilyen fejlesztések a piac fogadókészségét, együttműködését és az Ajánlás piacformáló hatását mutatják.

Az Ajánlás kapcsán kifejezett pozitív változások, jó gyakorlatok indukálódtak, amelyek közül kiemelendő az adatvédelmi fejlődés. Azon esetekben, ahol nem maga a biztosító vagy biztosításközvetítő üzemelteti a felületet, az ügyfelektől az adattovábbításhoz szinte kivétel nélkül hozzájárulást kérnek az intézmények az Ajánlás hatására.

Jelentős mértékben javult az e-felületek naprakészsége, az Ajánlást követően a frissítések közötti időközök lerövidültek. Az alapbiztosítási szerződéshez köthető kiegészítő fedezetek vagy együttkötési kedvezmények megjelenítése az Ajánlás hatására jelentős mértékben javult, de az együttkötési kedvezmény nem minden biztosítástípusnál kerül bemutatásra. 
A megjelenített biztosítási termékre vonatkozó jogszabályok felsorolására az Ajánlás kiadását követően több vizsgált esetben sor került, ahol a korábbiakban a jogszabályok nem voltak feltüntetve (fontos megjegyezni, hogy e tekintetben még számos intézmény esetén szükséges a fejlesztés).

Üdvözlendő változás, hogy figyelemfelhívó tájékoztatás került elhelyezésre az Ajánlás hatására az e-felületen történő összehasonlítás esetén számos olyan vizsgált közvetítőnél, ahol a közvetítő nem a teljes biztosítási piacot elemzi.

A gyakorlatban több esetben jelentős problémaként azonosítható volt, hogy az e-felület lehetőséget adott arra, hogy az e-ügyfél az ajánlatát meg tudja tenni azelőtt, hogy a szerződéskötést megelőző kötelező tájékoztatásra vonatkozó dokumentumokat megismerte volna, azaz tájékoztatás nem előzte meg a szerződéskötést. Kiemelendő pozitív változás, hogy az intézmények e-felületén ezen dokumentumok megismerésére vonatkozó check-boxokat helyeztek el, amelyek kipipálása a feltétele a biztosítási ajánlat megtételének.

További fejlesztés szükséges ugyanakkor az irányban, hogy az e-ügyfél önmagában azzal, hogy kipipálja ezen check-boxokat, ne tudjon továbblépni, kizárólag akkor, ha a tájékoztató dokumentumokat, hivatkozásokat ténylegesen meg is nyitotta, azaz a tájékoztatást megismerte. Az összetett, bonyolult vagy az átlagostól eltérő egyedi kockázatokat lefedő biztosítási fedezetek és szolgáltatások ajánlása esetén figyelmeztető szöveg került számos esetben elhelyezésre az e-felületen, azonban a kisebb közvetítők ezzel kapcsolatos gyakorlata továbbra sem megfelelö.

Tájékoztatási hiányosságként azonosította az MNB, hogy az e-felületen számos esetben nincs elhelyezve figyelemfelhívó tájékoztatás arra vonatkozóan, hogy a felület működtetése során okozott kárért vagy felmerült sérelemdíj megfizetéséért ki áll helyt.

Ezenkívül egyéb, olyan kérdések is azonosításra kerültek, ahol az MNB további fejlesztést vár el a piaci szereplőktől, így például a várakozási idő megjelenítésénél. Ezen túlmenően az összehasonlítási sorrend legtöbb esetben továbbra is kizárólag a biztosítási díjon alapul, a $\mathrm{TKM}^{\mathrm{Ny}}$ mértéke alapján rangsorolásra nem minden intézménynél van lehetőség, a rangsor egyes esetekben objektív mérőkkel nem igazolható, az e-ügyfél számára a szerződés létrejöttének és a kezdeményezés lehetséges visszautasításának szabályairól számos esetben nem nyújt kellő tájékoztatást, az alapbiztosítási szerződéshez köthető kiegészítő fedezetek vagy együttkötési kedvezmények a tájékoztatásokból sok esetben nem távolíthatóak el.

\section{Összegzés}

Az elektronikus közvetítők megjelenése, megerősödése jelentős hatást gyakorolt a biztosításközvetítők piacára, sok tekintetben revitalizálta a szektor müködését. A piaci hatásukkal kapcsolatban azt is látni kell, hogy csökkentették a termék összehasonlításának, keresésének költségeit, ezáltal a fogyasztók számára kedvezőbb díjszint alakult ki, ami hatékonyabb működésre késztette a többi csatornát is. Ez a hatás elsősorban a kgfb termékszegmensben figyelhető meg, ahol az elektronikus közvetítők átvették a dominanciát a személyes közvetítők helyett. Mindez a közvetítői piac jelentős átrendeződését eredményezte, ami jelenleg is zajlik. Az egyszerü/bevett termékek elektronikus értékesítése növekedésének lassulásával más, bonyolultabb termékszegmensekben figyelhető meg az elektronikus közvetítők útkeresése. A komplexebb termékek közvetítésére, pontosabban azok megkötésére az elektronikus közvetítői csatorna azonban annak korlátai miatt nem kifejezetten alkalmas, ezen esetekben leginkább támogató funkciót (például igényfelkeltés) tud megfelelően ellátni. Ehhez kapcsolódóan az is elmondható, hogy az ügyfelek ugyan szívesen tájékozódnak az elektronikus csatornán egyes termékekről, de egy idő után személyes (akár telefonos) kontaktust keresnek a közvetítővel. A két csatorna összekapcsolásának szükségességét jól mutatja az Osztrák Pénzügyi és Marketing Szövetség tanulmánya, miszerint a személyes tanácsadás hiánya korlátozza a pénzügyi termékek online térnyerését (a válaszadók 78\%-a konzultálna vásárlás előtt egy tanácsadóval ${ }^{19}$ ). Az Ajánlás az elektronikus értékesítés során egyes esetekben kifejezetten szükségesnek tartja az ügyfél személyes (szóbeli, online chat, online video) csatorna felé terelését. A komplexebb termékek esetében még inkább igaz, hogy a személyes vagy a telefonos és az elektronikus értékesítési csatornának egymást kiegészítve, támogatva kellene működnie, túllépve a mereven elválasztott külön-külön értékesítési csatornákban gondolkodáson, a versengő attitűd helyett a különböző csatornák összekapcsolásával szinergia jöhet létre.

\section{A személyes tanácsadás hiánya korlátozza \\ a pénzüigyi termékek online térnyerését.}

Az elektronikus közvetítők útkeresésének eredményeképpen mind mértékében, mind arányában elképzelhető további növekedés, amennyiben sikerül a kgfb-hez hasonló - „dobozos” vagy „dobozolható" - termékszegmenst találni, vagy a biztosítók ilyen termékeket tudnak fejleszteni, illetve korábbi termékeiket ilyen módon tudják átalakítani. Ugyanakkor érdemes figyelni arra a Nyugat-Európában már megindult folyamatra is, hogy a folyamatban lévő és új szociális, társadalmi trendek megrengethetik a hagyományos üzleti modelleket a biztositási szektorban, a vásárlók alkuerejének esetleges növekedése mellett egyidejűleg fellazulhat a közvetítők hagyományos szerepe, ha a fogyasztók egyre inkább közvetlenül a gyártótól vásárolnak. Az Ajánlás a jogszabályi kereteknek megfelelő közvetítői tevékenység elektronikus felületeken történő gyakorlati alkalmazására ad iránymutatást, illetve arra próbál válaszokat adni, hogyan lehet az elektronikus közvetítői felület továbbra is vonzó, kellő hozzáadott értéket képviselő, megbízható alternatíva az ügyfelek számára. 


\section{HIVATKOZÁSOK}

${ }^{1}$ John Burbank, a Nielsen Holdings N.V. globális információs és piackutató vállalat stratégiai kezdeményezésekért felelős elnöke. http://www.nielsen.com/hu/hu/press-room/2014/megduplazodott-az-online-vasarolni-szandekozok-aranya-2011-ota-p.html (2016.08.18.)

\section{IRODALOMJEGYZÉK}

1. KSH; Eurostat statikus táblák; https://www.ksh.hu/docs/hun/eurostat_tablak/index.html (2016.08.18.)

2. Report on cross-border e-commerce in the EU; February $2009 \mathrm{http}: / /$ ce.europa.eu/DocsRoom/documents/2787/attachments/1/ translations/en/renditions/pdf. (2016.08.18.)htp.//x.doi.org/10.1016/s0167-668/(03)00111-2

3. European-b2c-e-commerce-report-2015, Ecommerce Foundation, 2015 gyarorszag/ (2016.08.18.)

5. eNET - Telekom: „,elentés az internetgazdaságról” kutatás 2012 . 6. Mediascope Europe 2012: online media consump ion

cope-hazai-eredmenyei//more-2842 (2016.08.18.)
7. European-b2c-e-commerce-report-2015, Ecommerce Foundation, 2015

8 . Fülöp Attila. A biztositók értékesitési stratégíjínnak tám 9. Capgemini Analysis:Trends in Insurance Channels; https://www.de.capgemini.com/resource-file-access/resource/pdf/ Trends_in_Insurance_Channels.pdf (2016.08.18.)

Distribution Channels in Insurance, December 2013; http://www.panoramassicurativo.ania.it/get_file.php?id=15327 (2016.08.18.) https://www.uk.capgemini.com/resource-file-access/resource/pdf/trends_in_insurance_channels_2012.pdf (2016.08.18.)

10 .

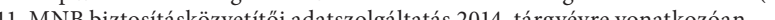

12. Dr. Mészáros Katalin PhD.: Marketing www.ktk.nyme.hu/fileadmin/dokumentumok/...MK_Marketing_lev.ppt (2016.08.18.) 13. http://dunder.hu/marketing/a-konverziooptimalizalas-es-a-vasarlas-pszichologiaja/ (2016.08.18.

14. Distribution Channels in Insurance, December 2013; http://www.panoramassicurativo.ania.it/get_file.php?id=15327 (2016.08.18.)

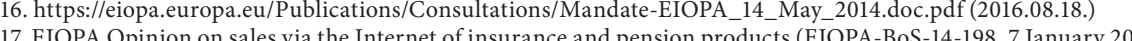

18. https://ec.europa.eu/eusurvey/runner/6906074f-1cca-44ea-aed7-e3fa659e645e?draftid=77fd00dd-c4bf-4451-841b-f2d79ca-

aafb9\&surveylanguage=HU\&serverEnev= (2016.08.18.)
19. Osztrák Pénzügyi és Marketing Szövetség tanulmánya, November 2013. 